(c) American Dairy Science Association, 2004.

\title{
A Multiple-Component Analysis of US Dairy Trade
}

\author{
K. W. Bailey \\ ${ }^{1}$ Department of Agricultural Economics and Rural Sociology, \\ The Pennsylvania State University, University Park 16802
}

\section{ABSTRACT}

This paper develops a multiple component-based methodology to account for imports and exports of dairy products and products with a significant dairy content. More specifically, it accounts for imports, exports, and net trade for all dairy products on the basis of milk fat, protein, other solids, and moisture. This approach provides a less biased method of assessing the amount of dairy imports entering the US than the USDA's milk equivalent conversions.

(Key words: multiple component analysis, dairy trade, milk equivalent conversions)

Abbreviation key: HTS = Harmonized Tariff Schedule; $\mathbf{M E}=$ milk equivalent, $\mathbf{M P C}=$ milk protein concentrate, $\mathbf{W T O}=$ World Trade Organization .

\section{INTRODUCTION}

The US dairy industry agreed to open its borders to greater market access under the Uruguay Round Trade Agreement that formed the World Trade Organization (WTO). The obvious trade-off was that the US would have greater access to other countries, particularly the European Union, and would thus have a greater opportunity to expand dairy trade. Since that time, the US experience with dairy trade has been increased imports of protein and milk fat-based dairy products. These imports are mostly in the form of cheese and dry protein products such as casein and milk protein concentrates (MPC). These imports were offset with lower-valued US dairy exports such as lactose and dry whey (USDA, Foreign Agriculture Service, 2002).

There is increased frustration from US dairy producers and their cooperatives that the WTO has resulted in more dairy imports with only limited opportunities for dairy exports. Under the tariff rate quota system adopted in the WTO, dairy quotas have increased over time and over-quota tariffs have declined. In some cases, imports beyond quota levels have increased when

Received June 15, 2003.

Accepted November 10, 2003.

E-mail: baileyk@psu.edu. the difference between world and US domestic prices has exceeded the over-quota tariff (i.e., butter blends). In other cases, there have been increased imports of dairy products not subject to the tariff rate quota system. These products have very low tariff levels and include casein and MPC. In other cases, importers have looked for alternative import classifications to lower overall duties. Chocolate block and butterfat blends, for example, have lower duties for milk solids than do overquota tariffs for whole milk powder or anhydrous milk fat.

The US government does not have an adequate methodology to quantify the amount of dairy imports entering the country. Currently, the USDA tracks imports of dairy items that fall under Chapter 4 of the Harmonized Tariff Schedule (HTS) and uses milk equivalent (ME) conversions to include imports in an estimate of a supply-and-demand balance for milk. If the USDA does not track all dairy ingredients entering the country, one can get a distorted picture of the supply and demand for major dairy products. For example, the USDA's estimate for the supply and demand for butter does not include imports of any milk fat blends or substitutes that lie outside Chapter 4 of the Harmonized Tariff Schedule. Thus, measures of domestic butter consumption will be distorted. In addition, the current methodology for quantifying dairy imports and exports does not allow one to judge what impact net trade in dairy products has on the competitiveness of the US dairy industry or on domestic milk prices.

This paper develops a multiple component-based methodology that account for imports and exports of dairy products. More specifically, it accounts for dairy products on the basis of milk fat, protein, other dairy solids, and moisture. This approach reflects not only traditional Chapter 4 dairy products, but all imports that contain major dairy components. Thus, imports that have both dairy and non-dairy ingredients are counted in the component calculations. This type of component accounting will allow analysts to compare imports with exports and net trade relative to components used in domestic dairy processing. This approach can also be used in a modeling framework to assess the impact of net trade on the US dairy industry. 


\section{Old System}

The USDA employs two methods of evaluating trade in dairy products. One approach is the quantity-value method. For example, the USDA's Foreign Agriculture Service reported in December 2002 that dairy exports over the period from January through September 2002 were $\$ 674.3$ million compared with imports over the same period of $\$ 1187.5$ million (USDA, Foreign Agriculture Service, 2002). This is a straightforward estimate of quantity and value of specific dairy products. The weakness with this approach, however, is that it 1) does not include all dairy and other products that contain significant quantities of dairy components (nondairy products) and 2) it provides no measure of either $\mathrm{ME}$ or dairy components.

The other method USDA uses to evaluate trade is to convert dairy products into an equivalent amount of milk employing ME conversion factors. The problem with using an ME approach, however, is that it does not yield a consistent measure of imports and exports. Depending on which conversion factor one uses, there are alternative amounts of imports and exports.

Milk equivalent conversion factors provide a simple method of presenting dairy trade figures to the industry. It has worked in the past mainly because of the fact that trade has been such a small part of the US supply-and-demand balance. Only recently have imports and exports increased significantly relative to either domestic production or commercial demand. Using this approach, all imports of specific dairy products (butter, cheese, skim milk powder, etc.) were converted from finished products into the equivalent amount of milk used to produce those products. For example, USDA reported that dairy imports in 2002 were 5.1 billion pounds on an ME, milk fat basis (USDA, Agricultural Marketing Service, 2003). An ME conversion on a milk fat basis merely converts imports of specific dairy products (such as butter) into a volume of milk needed to make those products. On an ME basis, imports were equivalent to $3 \%$ of production and/or commercial disappearance.

For example, suppose the US imported butter. The USDA would want to include that butter as imports in a supply-and-demand schedule for milk. Thus, they would first convert butter imports into some volume of raw milk using an ME conversion factor. These conversion factors take into consideration the relative component levels in a finished dairy product (i.e., butter) and raw milk. There are ME conversion factors on the basis of milk fat, protein, other dairy solids, or total milk solids.

The ME conversion factor for butter on a milk fat basis is as follows:

$$
M E_{b}^{m f}=\% M F_{b} / \% M F_{m}=82 / 3.67=22.34
$$

where $M E_{b}^{b f}=$ the ME of butter on a milk fat basis, $\% M F_{b}=$ percentage of milk fat in butter, and $\% M F_{m}=$ percentage of milk fat in raw milk. Thus, the ME of 1 $\mathrm{U}$ of butter on a milk fat basis is $22.34 \mathrm{U}$ of milk.

The US imported 7985 tonnes of butter in 2002 at an average milk fat content of $82 \%$. Thus, using an $\mathrm{ME}$ conversion of 22.34 , one can estimate that butter imports in 2002 were equivalent to 178,385 tonnes of raw milk. But the US also imported 11,360 tonnes of sweetened and unsweetened skim milk powder. With an average fat content of $<1 \%$, this same methodology would suggest that the raw $\mathrm{ME}$ of these imports is just 3095 tonnes on a ME, milk fat basis.

One can also choose to use an SNF ME measure. The SNF represents the protein, lactose, and ash in milk and typically averages $8.60 \%$ of raw milk (Jacobson, 1992). Thus, one can define a SNF conversion factor for skim milk powder as follows:

$$
M E_{s m p}^{s n f}=\% S N F_{s m p} / \% S N F_{m}=94 / 8.6=10.93
$$

where $M E_{s m p}^{s n f}=$ SNF ME for skim milk powder, $\% S N F_{m}=$ percentage of SNF in skim milk powder, and $\% S N F_{m}=$ percentage of SNF in raw milk. Using this measure of $\mathrm{ME}$, total skim milk powder imports of 11,360 tonnes now convert into 124,165 tonnes of raw milk. According to these calculations, the ME of skim milk powder imports on a SNF basis is one-third less than the ME of butter imports on a milk fat basis.

There are a number of inconsistencies when using this approach. One tonne of casein and 1 tonne of skim milk powder contain vastly different amounts of protein. One tonne of casein is about $87 \%$ protein, whereas 1 tonne of skim milk powder is only $35 \%$ protein. Yet the USDA uses a ME conversion factor (SNF basis) of 10.76 for casein and 11.19 for skim milk powder (USDA, Agricultural Stabilization and Conservation Service, 1991). Thus, the ME conversion factor can provide alternative estimates of the amount of raw milk used to make finished dairy products.

There is no end to the number of $\mathrm{ME}$ conversion factors one can compute. The Food, Agriculture, Conservation, and Trade Act of 1990 required the USDA to develop a new ME conversion formula to account for government purchases of surplus dairy products and imports on a "total solids" basis (USDA, Agricultural Stabilization and Conservation Service, 1991). This approach employed a simple weighting of MEs on a milk fat basis and SNF basis. One could construct an ME conversion on the basis of protein, ash, carbohydrates, etc. 


\section{MATERIALS AND METHODS}

An alternative approach is to account for all imports and exports on a component basis. This approach employs a "mass balance" theory that simply accounts for the major components of milk fat, protein, other solids, and moisture in finished dairy products. Such an approach traces the sources and uses of elements, nutrients, or dairy components through a system. For example, the Department of Defense used such an approach to study the health and environmental effects of recycled uranium (US Department of Energy, Office of Environment, Safety, and Health, 2001). The US government used uranium in nuclear weapons production. The spent uranium was then recycled, which generated a by-product stream. A mass balance approach was used to calculate how much uranium was initially processed, how much was recovered in recycling programs, what kinds of potent by-products were generated (plutonium, neptunium-237, fission products, etc.), and how these were recovered. By-products not recovered could pose a health or environmental threat. The mass balance approach is used in the literature for recycling, environmental pollution, and waste water systems (Solem, 2003; US Department of the Interior, 2000). This approach can be useful for analysis of the dairy industry as it has the potential to trace milk components from imports and domestic milk production throughout the entire US dairy industry. Protein, for example, can be traced from imports through cheese processing and on to the final consumer. In this study, we are merely accounting for milk components in imports and exports, which can be conceptualized as follows:

$$
\begin{gathered}
C_{m f}=\sum_{i} \beta_{b f}^{i} * X^{i}, \\
C_{p r}=\sum_{i} \beta_{p r}^{i} * X^{i}, \\
C_{o s}=\sum_{i} \beta_{o s}^{i} * X^{i}, \text { and } \\
\text { s.t. } \sum_{k} \beta_{k}^{i}=1
\end{gathered}
$$

where $C_{k}=$ tonnes of components k ( $m f=$ milk fat, $p r=$ protein, and os $=$ other solids) in finished dairy imports and exports, $X^{i}=$ dairy product $i$, and $\beta_{k}^{i}=$ percentage of component $k$ in dairy product $i$. In some cases, imports and exports may not be $100 \%$ pure dairy products, which is the case for ice cream and chocolate block. In these cases, one should use the following identity:

$$
C_{k}=\beta_{k}^{i} * X^{i} * \alpha^{i},
$$

where the tonnes of dairy component $k$ is computed by first estimating $\alpha^{i}$, the percentage of dairy solids in product $X^{i}$, and then estimating the dairy components of the remaining product on a percentage basis. Note that in this case, $\beta_{k}^{i}$ is the percentage of dairy component $k$ not in finished product $i$, but in the dairy solids contained in dairy product $i$.

\section{Data Sources and Component Methodology}

The first step in any analysis of dairy trade is amassing a list of products that contain dairy ingredients. The US Customs Service collects actual trade data from importers and exporters and furnishes it to the US Bureau of the Census. Data on individual products are based on the HTS classification system that was agreed to in the WTO. The actual data (both tariffs and trade) is reported by the US International Trade Commission (http://dataweb.usitc.gov/) and by the USDA (http://www.fas.usda.gov/ustrade/).

A final list of HTS codes was arrived at in Tables 2 and 4 for imports and exports. This list includes traditional Chapter 4 dairy products as well as other imports that contain a significant quantity of dairy products. One can also look at broad categories of dairy trade by using an HTS code at the 6-digit level. However, if one wants more specific information, such as whether a product is quota or non-quota, they must use an HTS code at the 10-digit level. Most of the HTS codes used here are at the HTS 6 level, although a few are HTS 8 and 10. The sources for this list of HTS codes and product descriptions were various USDA publications (USDA, Foreign Agriculture Service, 2002) and the National Milk Producer Federation's "Import Watch" publication (2003). The latter categorizes dairy imports on the basis of quota and non-quota dairy products.

In this report, dairy imports and exports were categorized by the author as follows.

- Fresh milk products (liquid products, yogurt, etc.)

- Cheese

- Butter and blends (butter, anhydrous milk fat, butter blends)

- Dry proteins (MPC, casein, whey, etc.)

- Lactose (major content is other solids)

- Milk powder (skim milk powder, whole milk powder, buttermilk)

All dairy products in Tables 2 and 4 are reported on a tonne basis. Trade in raw or packaged milk products is converted from liters to tonnes. 
Table 1. Conversions of US imports of milk and cream from liters to kilograms based on temperature and milk components. ${ }^{1}$

\begin{tabular}{lccll}
\hline $\begin{array}{l}\mathrm{HTS}^{2} \\
\text { Code }\end{array}$ & $\begin{array}{l}\text { Milk fat } \\
\text { percentage }\end{array}$ & $\begin{array}{l}\text { SNF } \\
\text { percentage }\end{array}$ & $\begin{array}{l}\text { Temperature } \\
\left({ }^{\circ} \mathrm{C}\right)\end{array}$ & $\begin{array}{l}\text { Density } \\
(\mathrm{kg} / \mathrm{L})\end{array}$ \\
\hline 040110 & 0.5 & 9.5 & 4 & 1.037741 \\
040120 & 5.0 & 8.0 & 4 & 1.030469 \\
040130 & 40.0 & 10.0 & 4 & 1.025077 \\
\hline
\end{tabular}

${ }^{1}$ Based on Equation [8].

${ }^{2}$ HTS $=$ Harmonized Tariff Schedule.

The cheese category for imports contains an aggregated group of products. The HTS code 040610 is for fresh or unripened or uncured cheese, including whey cheese and curd. If one breaks out this category to an
HTS 10 code level, one can observe quota and overquota imports for Chongos, fresh cheese curd, Blue Mold, Cheddar, American, Edam/Gouda, Italian, Swiss/ Emmentaler, skim milk, and other fresh cheese. The

Table 2. Imports of dairy products from 1997 to 2002 (USDA Foreign Agriculture Service, Available: http://www.fas.usda.gov/ustrade/).

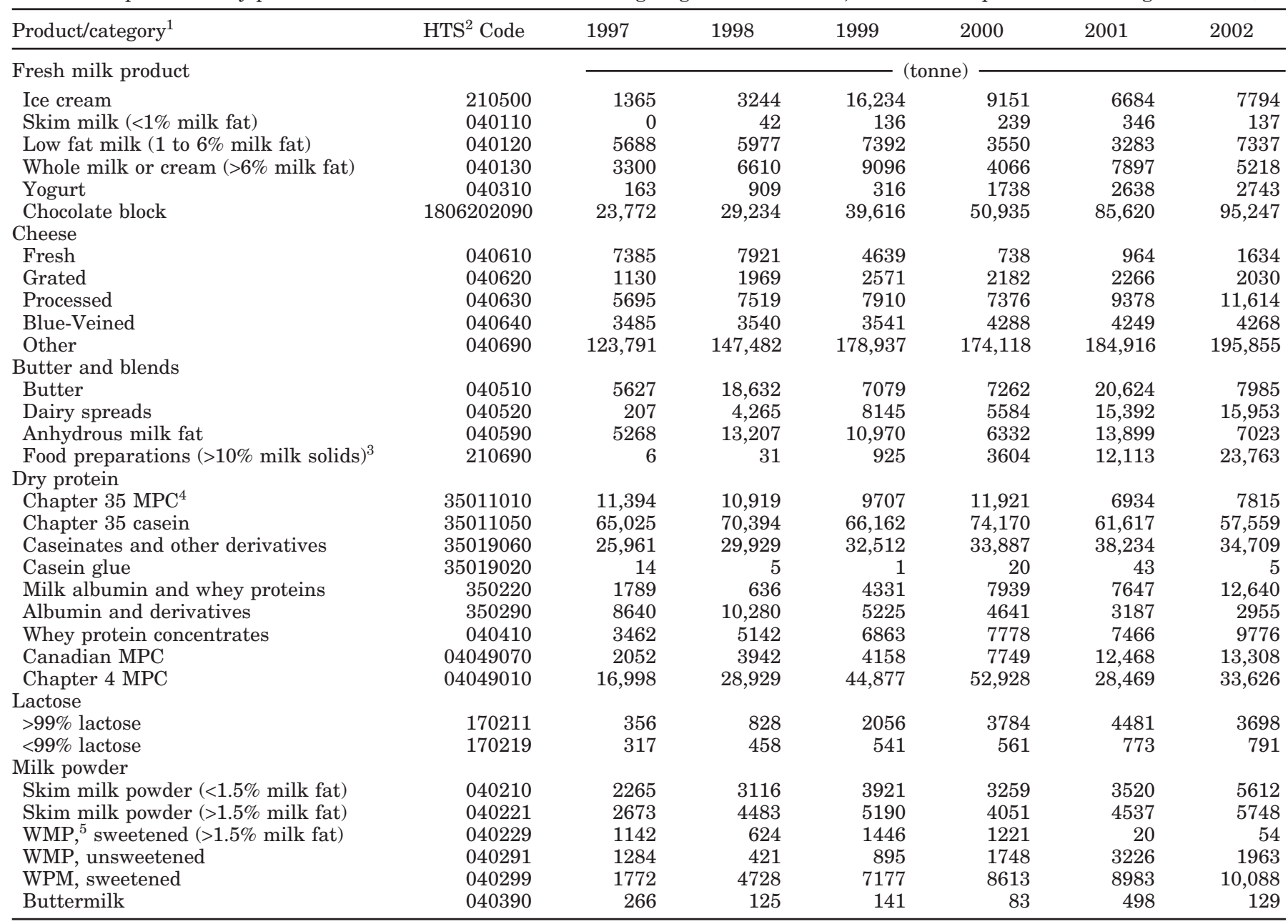

${ }^{1}$ Description available: http://www.fas.usda.gov/USTrade/ustlists/ImChapter.asp?QI=.

${ }^{2}$ HTS = Harmonized Tariff Schedule .

${ }^{3}$ Reflects 6400 (quota) and 6600 (over quota).

${ }^{4} \mathrm{MPC}=$ Milk protein concentrate.

${ }^{5} \mathrm{WMP}=$ Whole milk powder. 
Table 3. Component content of dairy solids in dairy product imports (Source: http://www.nal.usda.gov/fnic/ foodcomp/Data/SR14/sr14.html).

\begin{tabular}{|c|c|c|c|c|}
\hline \multirow[b]{2}{*}{ Product/category } & \multirow[b]{2}{*}{ HTS $^{1}$ Code } & \multicolumn{3}{|c|}{ Dairy solids } \\
\hline & & Protein & Milk fat & Other solids \\
\hline \multicolumn{5}{|l|}{ Fresh milk products } \\
\hline Ice cream & 210500 & 18.0 & 54.0 & 28.0 \\
\hline Skim milk (<1\% milk fat) & 040110 & 3.5 & 0.5 & 6.0 \\
\hline Low fat milk ( 1 to $6 \%$ milk fat) & 040120 & 3.5 & 5.0 & 4.5 \\
\hline Whole milk or cream ( $>6 \%$ milk fat) & 040130 & 3.5 & 40.0 & 6.5 \\
\hline Yogurt & 040310 & 4.5 & 3.0 & 7.5 \\
\hline Chocolate block & 1806202090 & 26.3 & 26.7 & 44.5 \\
\hline \multicolumn{5}{|l|}{ Cheese } \\
\hline Fresh & 040610 & 23.0 & 35.0 & 5.0 \\
\hline Grated & 040620 & 23.0 & 35.0 & 5.0 \\
\hline Processed & 040630 & 22.2 & 31.3 & 7.4 \\
\hline Blue-Veined & 040640 & 21.4 & 28.7 & 7.5 \\
\hline Other & 040690 & 23.0 & 35.0 & 5.0 \\
\hline \multicolumn{5}{|l|}{ Butter and blends } \\
\hline Butter & 040510 & 0.0 & 82.0 & 2.0 \\
\hline Dairy spreads & 040520 & 0.0 & 82.0 & 2.0 \\
\hline Anhydrous milk fat & 040590 & 0.0 & 99.0 & 1.0 \\
\hline Food preparations $(>10 \% \text { milk solids })^{2}$ & 210690 & 0.0 & 100.0 & 0.0 \\
\hline \multicolumn{5}{|l|}{ Dry protein } \\
\hline Chapter $35 \mathrm{MPC}^{3}$ & 35011010 & 90.0 & 1.0 & 1.0 \\
\hline Chapter 35 casein & 35011050 & 87.0 & 1.0 & 2.0 \\
\hline Caseinates and other derivatives & 35019060 & 91.0 & 2.0 & 2.5 \\
\hline Casein glue & 35019020 & 90.0 & 1.0 & 4.0 \\
\hline Milk albumin and whey proteins & 350220 & 80.0 & 6.0 & 9.0 \\
\hline Albumin and derivatives & 350290 & 80.0 & 7.0 & 8.0 \\
\hline Whey protein concentrates & 040410 & 34.0 & 7.0 & 54.0 \\
\hline Canadian $\mathrm{MPC}^{4}$ & 04049070 & 12.0 & 2.0 & 81.0 \\
\hline Chapter 4 MPC & 04049010 & 65.0 & 2.0 & 28.0 \\
\hline \multicolumn{5}{|l|}{ Lactose } \\
\hline$>99 \%$ lactose & 170211 & 0.0 & 0.0 & 100.0 \\
\hline$<99 \%$ lactose & 170219 & 0.0 & 0.0 & 100.0 \\
\hline \multicolumn{5}{|l|}{ Milk powder } \\
\hline Skim milk powder $(<1.5 \%$ milk fat $)$ & 040210 & 35.0 & 1.0 & 59.0 \\
\hline Skim milk powder ( $>1.5 \%$ milk fat $)$ & 040221 & 26.0 & 1.0 & 68.0 \\
\hline WMP, sweetened ( $>1.5 \%$ milk fat) & 040229 & 10.0 & 5.0 & 80.0 \\
\hline WMP, unsweetened & 040291 & 7.5 & 7.5 & 10.0 \\
\hline WPM, sweetened & 040299 & 26.0 & 26.0 & 43.0 \\
\hline Buttermilk & 040390 & 34.0 & 48.0 & 13.0 \\
\hline
\end{tabular}

\footnotetext{
${ }^{1} \mathrm{HTS}=$ Harmonized Tariff Schedule.

${ }^{2}$ Binding Customs tariff rulings (http://rulings.customs.gov/, http://www.customs.ustreas.gov/xp/cgov/import/) indicate this product is mainly $95 \%$ milk fat and $5 \%$ non-dairy solids. Thus, one can assume the product is $95 \%$ dairy, and $100 \%$ of this is milk fat.

${ }^{3} \mathrm{MPC}=$ Milk protein concentrate.

${ }^{4}$ This product is imported from Canada and is not a MPC. Most binding tariff rulings indicate that it could be composed of various dairy solids. However, a review of the CIF customs value suggests it has very little protein in it.
}

HTS code 040620 is for grated or powdered cheeses and reflects quota and over-quota imports of Stilton, Cheddar, Edam/Gouda, Italian, Sheep cheese, Cheddar blend, American blend, Edam/Gouda blend, Italian blend, Swiss/Emmentaler blend, skim milk blend, and other cheese blends. The HTS code 040630 reflects processed cheese, not grated or powdered, for quota and over-quota cheeses such Stilton, Blue Vein and blends, Cheddar and blends, Colby, Edam/Gouda and blends, Gruyere, Sheep, American blends, Italian blends,
Swiss/Emmentaler blends, skim milk, and other cheese blends. The HTS code 040640 reflects Blue Veined cheeses with quota and over-quota cheeses such as Roquefort, Stilton, and Blue Vein. Finally, HTS code 040690 reflects quota and over-quota imports for other cheeses. This category contains 45 HTS codes at the 10-digit level for cheeses such as Gjetost, Sbrinz, Sheep, Gammelost, etc.

The component levels for milk fat, protein, and other solids reported in Table 3 are a simple average of the 
Table 4. Exports of dairy products from 1997 to 2002 (USDA, Foreign Agriculture Service, Available: http://www.fas.usda.gov/ustrade/).

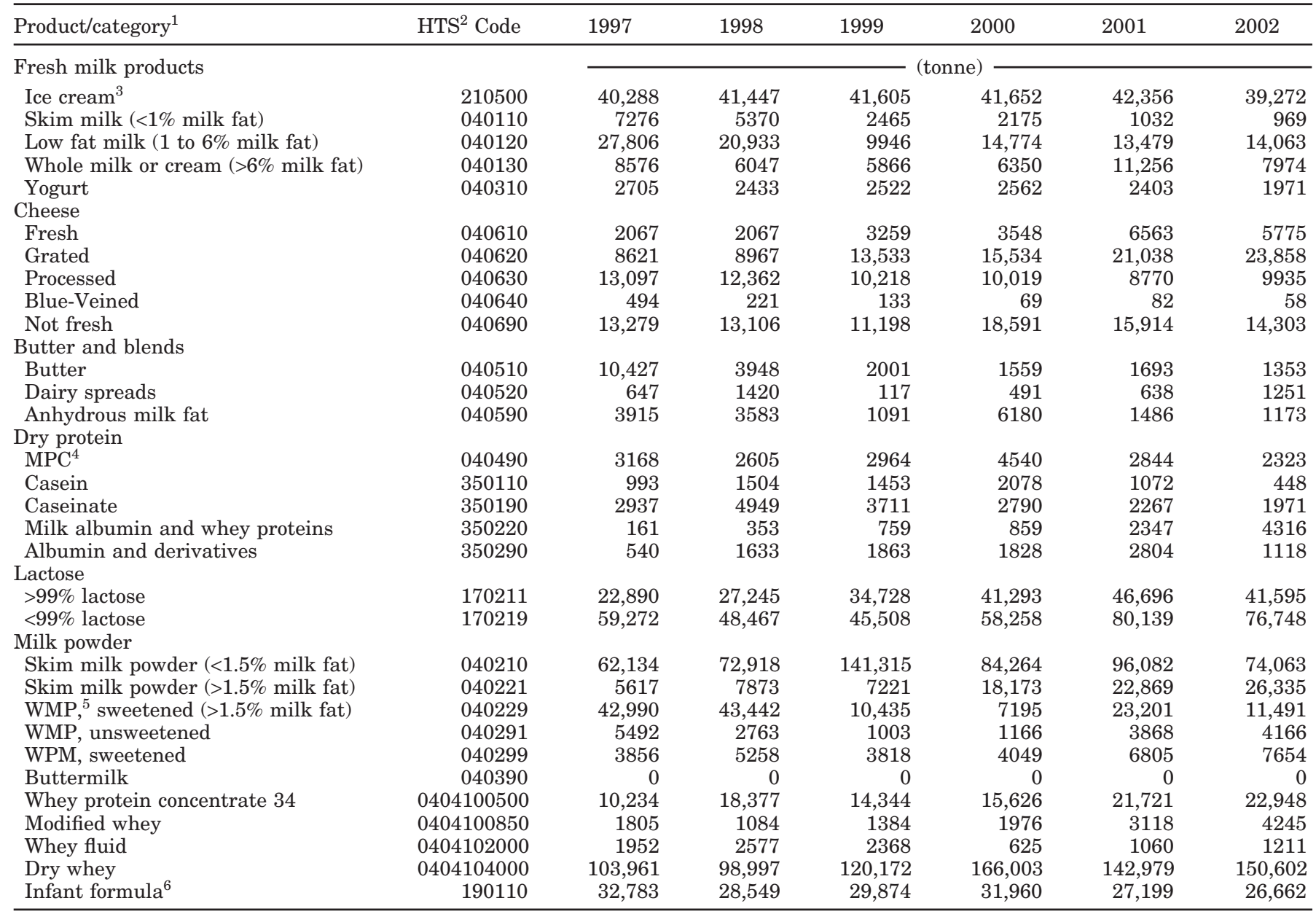

${ }^{1}$ Code description available: http://www.fas.usda.gov/USTrade/ustlists/ImChapter.asp?QI=.

${ }^{2}$ HTS $=$ Harmonized Tariff Schedule.

${ }^{3}$ Raw product weight. However, only $20 \%$ is dairy solids (National Archives and Records Administration, 2002).

${ }^{4} \mathrm{MPC}=$ Milk protein concentrate.

${ }^{5} \mathrm{WMP}=$ Whole milk powder .

${ }^{6}$ Raw product weight.

various cheeses in each category. The approach used here is reflective of the components in these 5 cheese import groupings and greatly simplifies the analysis.

It is important to note that to evaluate the effects of trade on the US dairy industry, one must trace each of these imported dairy products through the entire US dairy industry. This is a difficult task, as it requires an analysis of US milk production, processing, and supply and demand for many different dairy products. The approach used here is simpler because it allows one to add up the milk components in dairy trade and compare this with the milk components in the US production of milk.

The approach developed in this study was to compute the component content of all dairy exports and imports by product category and to compute a measure of net trade. The building blocks for this approach are contained in Tables 3 and 5, which contain assumptions regarding the percentage of dairy components in imports and exports. The dairy trade numbers and the dairy content of the data are first estimated. Then, the component content is analyzed. The major source for information used in this analysis for component content analysis is the USDA Nutrient Database (USDA, Agricultural Research Service, 2002). Another source was the Code of Federal Regulation that sets component standards for some US dairy products (National Archives and Records Administration, 2002).

The dairy components were analyzed on the basis of the following components: milk fat, protein (crude), 
Table 5. Component content of dairy solids in dairy product exports (Source: http://www.nal.usda.gov/fnic/ foodcomp/Data/SR14/sr14.html).

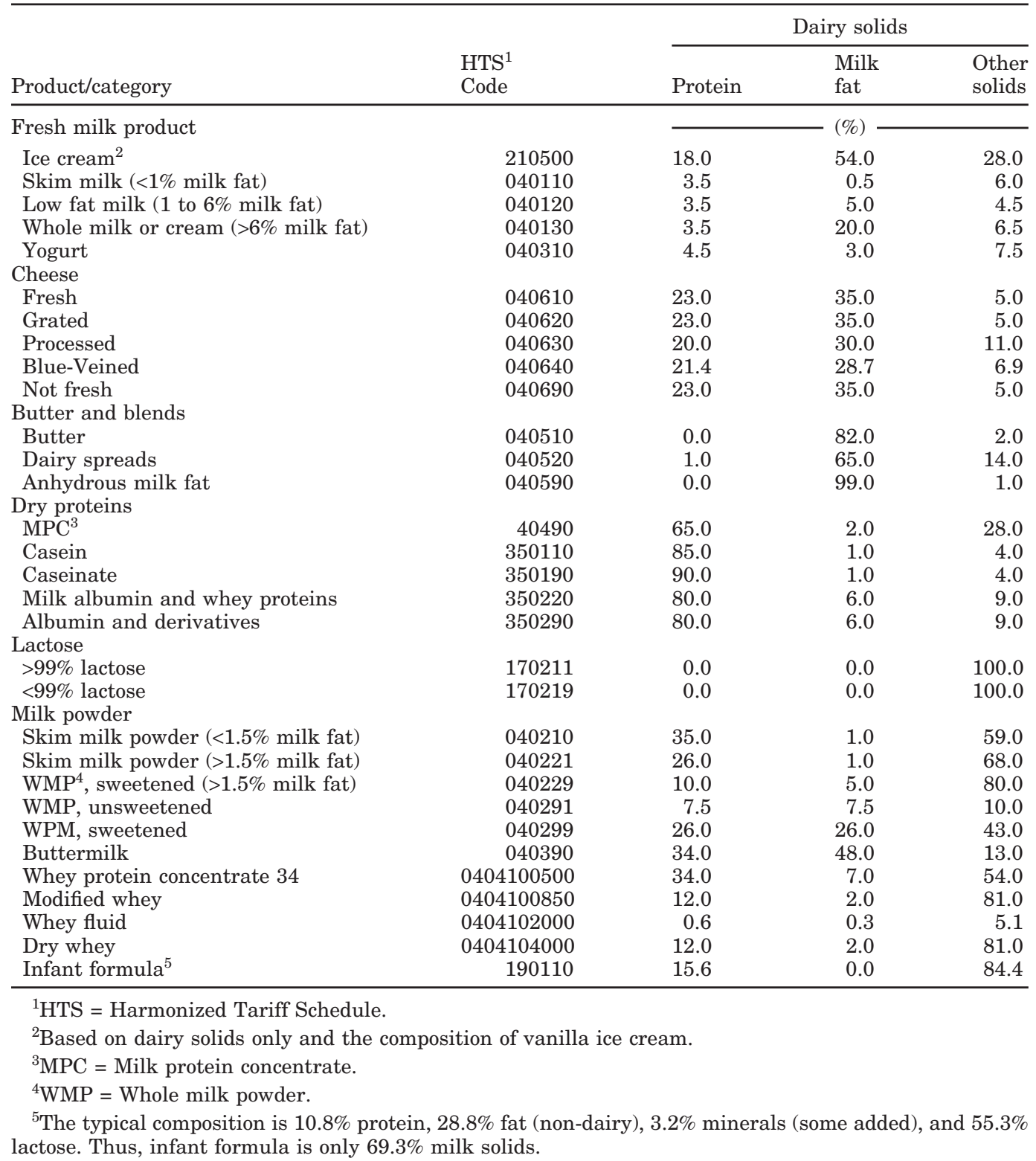

other solids, and moisture. These components total $100 \%$. Thus, in Table 3 the protein content of fresh, grated, and other cheese was $23 \%$, the milk fat content was $35 \%$, and the other solids portion was $5 \%$ with the balance moisture. This is fairly straightforward for simple dairy products such as butter, skim milk powder, dry whey, etc.

There are a number of exceptions to this rather straightforward analysis. The analysis was more complex for fluid milk, ice cream, chocolate block, food preparations, and infant formulas. In these cases, dairy ingredients are mixed with non-dairy ingredients. Following Equation [7], the proportion of dairy ingredients in the finished product is estimated first, then the dairy component content.

\section{Fluid Milk}

The US imports fluid milk either in raw form (from Canada) or packaged form. There are 3 general HTS classifications for fluid milk. The HTS 040110 classification describes milk and cream of a milk fat content not exceeding $1 \%$ by weight. The HTS 040120 classification is milk and cream of a milk fat content exceeding $1 \%$ but not exceeding 6\%. Finally, HTS 040130 is for milk and cream with a milk fat content exceeding $6 \%$. 
The data for these HTS codes are reported in liters. Thus, for this analysis one must convert liters to tonnes. However, one would expect the conversion to vary with the component content of the milk.

Watson and Tittsler (1961) and later Webb et al. (1974) quantified the relationship between milk density and temperature and milk components in the following equation:

$$
\begin{gathered}
\mathrm{D}=1.003073-0.000179 \times \mathrm{T}-0.000368 \\
\times \mathrm{BF}+0.003744 \times \mathrm{NF}
\end{gathered}
$$

where $\mathrm{D}=$ milk density, $\mathrm{T}=$ temperature, $\mathrm{BF}=$ percentage of milk fat, and NF = percentage of nonfat milk solids. This equation applies to temperature ranges of 1 to $10^{\circ} \mathrm{C}$. In this study, we will assume a temperature of $4^{\circ} \mathrm{C}$ to represent chilled milk. Table 1 illustrates the conversions that can be constructed from Equation [8] based on component assumptions in Table 3. Thus, to convert liters of HTS 040110, simply multiply milk imports by 1.037741 to get kilograms, and then divide by 1000 to get tonnes.

\section{Ice Cream}

The US exports a fairly significant quantity of ice cream. The US exported 41,103 tonnes of ice cream over the period from 1997 to 2002 . Title 21, Part 135 of the Code of Federal Regulations (National Archives and Records Administration, 2002) requires ice cream to contain not less than $0.726 \mathrm{~kg}(1.6 \mathrm{lb})$ of total solids per gallon and weigh not less than $2.04 \mathrm{~kg}(4.5 \mathrm{lb})$ to the gallon. It should contain not less than $10 \%$ milk fat, nor less than $10 \%$ nonfat milk solids. (Ice cream that contains a milk fat level $>10 \%$ is allowed to have a lower minimum nonfat solids content.) Thus, one can make the following assumptions for the ice cream category. First, ice cream must be $35.6 \%$ total solids. Second, ice cream must be at least $20 \%$ dairy solids. By implication, ice cream is around $15.6 \%$ non-dairy solids (sweeteners, stabilizers, and flavors).

Thus, one can multiply ice cream exports by $20 \%$ to determine ice cream exports on a dairy solids basis. Next, one must make some assumptions regarding the dairy component content of the dairy solids. This cannot be done with tremendous precision because there are many different types of ice creams that are traded. In addition, some of the ice cream categories could be ice cream mixes. To simplify the analysis, we have made the assumption that the average component analysis of the ice cream category will be similar to that of vanilla ice cream, which is also the most processed ice cream in the US. It should be noted that the component levels for ice cream in Tables 3 and 5 are not for the raw product, but are for the dairy solids only.

\section{Chocolate Block}

Imports of chocolate block have grown $300 \%$ between 1997 and 2002. The Customs definition of this product is that it must contain chocolate in blocks or slabs, as well as milk fat or other milk solids (US Customs, 2003). The total milk solids are limited to $32 \%$. In reality, chocolate block is compressed sugar, cocoa, and dairy products such as whole milk powder, milk fat (anhydrous milk fat), skim milk powder, or dry whey. Thus, one can make the simplifying assumption that $32 \%$ of the composition of chocolate block is a dairy product that is very close to whole milk powder. The USDA has determined that the composition of the latter is $26.3 \%$ protein, $26.7 \%$ milk fat, and $44.5 \%$ other dairy solids.

\section{Infant Formulas}

The US exports of infant formulas have averaged 29,505 tonnes over the period from 1997 to 2002. Although some exports of infant formulas are likely to be liquid, most are powdered products. The USDA database was used to approximate a typical infant formula (Ross Similac, low iron, powder, not reconstituted). The label indicates that this product contains skim milk powder, lactose, and whey protein concentrate. The composition is $10.8 \%$ protein, $28.8 \%$ fat (from non-dairy sources), $3.2 \%$ minerals (mainly dairy sources), and $55.3 \%$ carbohydrates or lactose. Thus, the dairy solids content of this product is $69.3 \%$.

\section{Butter Blends}

Another category of dairy imports is milk fat blends. There are Chapter 4 butter blends (04052070, overquota category), and Chapter 21 food preparation milk fat blends (21069066, over quota). The latter is listed by Customs (US Customs, 2003) as a Food Preparation that must contain at least $10 \%$ milk solids, but, in reality, it reflects imported milk fats, mainly anhydrous milk fat. The imports for this general category have risen from 6 tonnes in 1997 to 23,763 tonnes. This reflects both the quota (HTS 2106906400) and over quota (HTS 2106906600). To gain a general idea of what this product is, one can review the binding tariff rulings issued by the US Customs Service. Most show that the product contains 89 to $97 \%$ milk fat, with the rest of the product containing salt, sugar, and other nondairy products. For example, the Customs Rulings Online Search System (CROSS) (US Customs, 2003) for fat blends produced a letter dated May 17, 2001 (NY 
Table 6. Computed dairy components in imports and exports.

\begin{tabular}{|c|c|c|c|c|c|c|}
\hline & 1997 & 1998 & 1999 & 2000 & 2001 & 2002 \\
\hline \multirow{2}{*}{\multicolumn{7}{|c|}{ Imports }} \\
\hline & & & & & & \\
\hline Protein & 148,324 & 171,291 & 182,734 & 199,938 & 185,242 & 193,276 \\
\hline Milk fat & 66,328 & 100,725 & 107,444 & 97,332 & 134,262 & 125,176 \\
\hline Other solids & 28,302 & 40,478 & 53,738 & 61,220 & 65,038 & 72,191 \\
\hline \multicolumn{7}{|l|}{ Exports } \\
\hline Protein & 66,095 & 74,677 & 95,515 & 87,499 & 95,056 & 87,929 \\
\hline Milk fat & 40,104 & 34,847 & 28,734 & 37,801 & 37,989 & 37,047 \\
\hline Other solids & 278,536 & 277,422 & 309,782 & 341,059 & 375,610 & 354,625 \\
\hline
\end{tabular}

H80030). That letter was in reference to a tariff classification ruling on food ingredients. Both products discussed contained $95 \%$ anhydrous milk fat, with the balance either salt or sugar.

Food preparation milk fat blends are used as ingredients in the production of many food items, mainly confectionery and cheese food products. The reported duty rate was $10 \%$ ad valorem for imports within a small quota of 4105 tonnes described in additional US Note 10 to Chapter 4 of the HTS. Milk fat blends are just one of the different dairy products that could be imported under this quota. Both butter and milk fat blends have duty rates within a quota and much higher rates of duty outside of quota. For example, the duty rate on over-quota butter is $\$ 1.541 / \mathrm{kg}(\$ 0.70 / \mathrm{lb})$ or $67 \%$ of the US support price $(\$ 1.05 / \mathrm{lb})$. The over-quota duty on milk fat blends for both Chapter 4 and 21 butter blends is $\$ 0.704 / \mathrm{kg}$ plus $8.5 \%$ ad valorem (of the declared value price). Assuming an international price of $\$ 1400 /$ tonne, the over-quota duty is equal to $35 \%$ of the support price. Therefore, the rate of over-quota duty is lower on the milk fat blends than on butter or anhydrous milk fat. Thus, it is economically more favorable to import overquota butter blends in preference to butter when world and domestic prices exceed the over-quota rate of duty.

\section{RESULTS AND DISCUSSION}

The data in Tables 2 through 5 were used to compute the total volume of imports and exports of dairy ingredients milk fat, protein, and other solids. These results are presented in Table 6 . They clearly show two trends over the period from 1997 to 2002 . First, the US imports far more protein than either milk fat or other solids. The analysis indicates that 2002 imports included 193,276 tonne of protein, 125,176 tonne of milk fat, and 72,191 tonne of other solids. Over the period from 1997 to 2002, imports rose $30.3 \%$ for protein, $88.7 \%$ for milk fat, and $155.1 \%$ for other solids. The major source of protein imports was dry proteins, such as casein, caseinates, albumin, and MPC, followed by cheese imports.
A second major trend is that the US exports far more "other solids" than either milk fat or protein. For example, in 2002 , the US exported 354,625 tonne of other solids, 87,929 tonne of protein, and 37,047 tonne of milk fat. Most of this "other solids" category was exports of milk powders (dry whey, skim milk powder, and infant food) and lactose.

Net trade is computed next in Table 7 (imports less exports). These data clearly show that over the period from 1997 to 2002 the US was a net importer of protein and milk fat and a net exporter of other solids. Lactose and milk powder accounts for the bulk of US exports. Cheese, butter and blends, and dry proteins account for the bulk of imports of milk fat and protein. These import levels are offset to some extent by exports of skim milk powder under the Dairy Export Incentive Program.

This study provides a very different methodology for accounting for dairy trade than does the USDA. A comparison is made in Table 8. The USDA reports dairy imports on an ME, milk fat basis. The imports that enter this calculation are all Chapter 4 dairy imports from the HTS. This calculation does not include other sources of imported milk fats that may be in non-Chapter 4 imports (i.e., food preparations). For 2002, the USDA reported total milk imports of 2.3 million tonne. Using the methodology employed in this study, the milk fat contained in all dairy imports in 2002 (Table 6) amounts to 125,176 tonne, which is converted to an ME, milk fat conversion by multiplying by 100/3.67. Thus, our estimates are for total milk imports on a milk fat basis of 3.4 million tonne, which is $47.4 \%$ greater than the USDA estimate.

\section{CONCLUSIONS}

This study provides a new methodology for computing net trade for dairy products. It avoids the distortions provided by $\mathrm{ME}$ conversions that attempt to convert all dairy products into an equivalent amount of milk. Instead, this method takes imports and exports of finished dairy products and computes the components that 
Table 7. Net dairy imports by product classification on a dairy component basis.

\begin{tabular}{|c|c|c|c|c|c|c|}
\hline & 1997 & 1998 & 1999 & 2000 & 2001 & 2002 \\
\hline \multicolumn{7}{|l|}{ Protein summary } \\
\hline Fresh milk products & -719 & 338 & 2280 & 2547 & 5445 & 6569 \\
\hline Cheese & 24,200 & 30,546 & 36,814 & 32,587 & 34,480 & 37,341 \\
\hline Butter blends & -6 & -14 & -1 & -5 & -6 & -13 \\
\hline Dry protein & 105,151 & 116,965 & 119,434 & 137,598 & 116,922 & 120,664 \\
\hline Lactose & 0 & 0 & 0 & 0 & 0 & 0 \\
\hline Milk powder & $-46,395$ & $-51,222$ & $-71,306$ & $-60,288$ & $-66,654$ & $-59,213$ \\
\hline Total & 82,230 & 96,614 & 87,220 & 112,439 & 90,186 & 105,347 \\
\hline \multicolumn{7}{|l|}{ Milk fat summary } \\
\hline Fresh milk products & -3744 & -939 & 3007 & 649 & 3949 & 4976 \\
\hline Cheese & 36,629 & 46,226 & 55,741 & 49,290 & 52,118 & 56,420 \\
\hline Butter blends & -2847 & 24,062 & 21,088 & 10,230 & 43,089 & 28,834 \\
\hline Dry protein & 2474 & 2951 & 3227 & 3797 & 3075 & 3539 \\
\hline Lactose & 0 & 0 & 0 & 0 & 0 & 0 \\
\hline Milk powder & -6288 & -6422 & -4353 & -4435 & -5956 & -5640 \\
\hline Total & 26,224 & 65,878 & 78,710 & 59,530 & 96,274 & 88,129 \\
\hline \multicolumn{7}{|l|}{ Other solids summary } \\
\hline Fresh milk products & -747 & 972 & 4036 & 4614 & 9512 & 11,344 \\
\hline Cheese & 4625 & 6110 & 7627 & 6730 & 7275 & 7880 \\
\hline Butter blends & -165 & 362 & 510 & 270 & 1029 & 655 \\
\hline Dry protein & 10,100 & 16,049 & 21,407 & 27,125 & 23,911 & 27,708 \\
\hline Lactose & $-81,489$ & $-74,425$ & $-77,638$ & $-95,205$ & $-121,582$ & $-113,854$ \\
\hline Milk powder & $-182,560$ & $-186,011$ & $-211,986$ & $-223,372$ & $-230,717$ & $-216,168$ \\
\hline Total & $-250,235$ & $-236,943$ & $-256,044$ & $-279,839$ & $-310,571$ & $-282,435$ \\
\hline
\end{tabular}

they contain. In addition, this method classifies imports and exports according to 6 product categories (fresh milk products, cheese, butter and blends, dry protein, lactose, and milk powder). This method clearly illustrates the tonnes of milk components that are imported and exported. Such an approach could then be used to compute the impact of trade on the US dairy industry. For example, in 2002 US dairy farmers marketed 76.5 million tonne of milk. Assuming an average protein content of $3.2 \%$, that represents 2.5 million tonne of protein. Thus, the protein contained in imports in 2002 was equivalent to $7.9 \%$ of domestic production. One could argue that that is not an insignificant amount of protein and could have had a market impact. In a more complex model, one could compare imports or net imports of protein, butterfat, or other dairy solids with domestic consumption.
This study clearly illustrates that US exports of both protein and milk fat have been relatively flat over the period from 1997 to 2002 . The only growth in exports has been for other dairy solids, mainly whey and lactose. These are products that are priced on the international market and are not directly purchased under the dairy price support program. Unfortunately, they are also low-value dairy products. Higher value dairy products such as cheese, butter, and nonfat dry milk, which contain milk fat and protein and are priced domestically well above international prices, have not shown much export growth.

The US imports have shown significant growth over the period from 1997 to 2002 . Imports of butterfat, protein, and other solids have all shown significant growth, particularly products such as MPC, chocolate block, and butterfat blends. These are products that are not re-

Table 8. Comparison of USDA estimates of dairy imports with proposed methodology. (Source: USDA/ERS, Livestock, Dairy, and Poultry Outlook, LDP-M-109, July 22, 2003, p 31)

\begin{tabular}{|c|c|c|c|c|c|c|}
\hline & 1997 & 1998 & 1999 & 2000 & 2001 & 2002 \\
\hline Million pounds & 2900 & 3813 & 4772 & 4445 & 5716 & 5103 \\
\hline Tonnes & $1,315,431$ & $1,729,565$ & $2,164,565$ & $2,016,239$ & $2,592,761$ & $2,314,706$ \\
\hline Computed imports of milk fat, tonne & 66,328 & 100,725 & 107,444 & 97,332 & 134,262 & 125,176 \\
\hline ME conversion, tonne ${ }^{2}$ & $1,807,296$ & $2,744,562$ & $2,927,620$ & $2,652,097$ & $3,658,374$ & $3,410,789$ \\
\hline Percent change from USDA estimate & 37.4 & 58.7 & 35.3 & 31.5 & 41.1 & 47.4 \\
\hline
\end{tabular}

${ }^{1}$ Milk equivalent (ME), milk fat basis.

${ }^{2}$ Assumes a milk equivalent, milk fat conversion of 27.25. 
flected under the traditional Chapter 4 heading of the HTS. In fact, it is clear that the USDA is not adequately tracking these imports. The methodology outlined in this study, however, does incorporate trade in these products and accounts for their milk components.

The authors recommend that the USDA employ this methodology to account for imports and exports of dairy products. The approach is flexible enough to include many imports outside of Chapter 4 of the HTS, which will provide a more comprehensive reflection of trade. It is also simple to implement in a database program. United States Customs provides monthly import data. Thus, the USDA merely needs to convert this data into dairy components. The only concern is which imported products will be included and which will be excluded from the analysis. The USDA will need to set a methodology that will only incorporate a new HTS code into the analysis when it reaches a specific level of dairy content.

\section{REFERENCES}

Bailey, K. 2003. Impact of MPC imports on 2002 U.S. cheese production. Staff Paper \#362, Department of AERS, The Pennsylvania State University. Available: http://dairyoutlook.aers.psu.edu/reports/Pub2003/staffpaper362.pdf. Accessed June 1, 2003.

Jacobson, R. 1992. Calculating milk equivalents: Milk fat or total solids basis. P-2, Dairy Markets and Policy Issues and Options, Cornell Univ., Ithaca, NY.

National Archives and Records Administration. 2002. Code of Federal Regulations. Available: http://www.access.gpo.gov/nara/cfr/. Accessed Jan 1, 2003.
National Milk Producers Federation. Import Watch. Various issues. Available: http://www.nmpf.org/meData/index.cfm. Accessed June 1, 2003.

Solem, H. Efficiency in a waste treatment system: A mass balance approach. Dept. Econ., Norwegian Univ. Sci. Technol, Trondheim. Available: http://www.sv.ntnu.no/iso/Havard.Solem/ Recycling1.pdf. Accessed June 1, 2003.

United States Customs. 2003. CROSS: Customs rulings online search system. Available: http://rulings.customs.gov/. Accessed June 1, 2003

USDA, Agricultural Marketing Service. 2003. Dairy Market News. 70 (Rep. 9, Feb. 24-28):13.

USDA, Agricultural Stabilization and Conservation Service. 1991. Methodology of calculating the milk equivalent, total solids basis, of CCC purchases of surplus dairy products and of imports of dairy products, Handout.

USDA, Agricultural Research Service. 2002. USDA national nutrient database for standard reference, Release 15. Nutrient Data Laboratory Home Page. Available: http://www.nal.usda.gov/fnic/foodcomp. Accessed Jan 1, 2003.

United States Department of Energy, Office of Environment, Safety, and Health. 2001. A preliminary review of the flow and characteristics of recycled uranium throughout the DOE complex: 19521999. F-001-001. Available: http://tis.eh.doe.gov/legacy/reports/ reports.html. Accessed June 1, 2003.

USDA, Foreign Agriculture Service. 2002. Dairy: World markets and trade. Available: http://www.fas.usda.gov/dlp/circular/2002/0212Dairy/toc.htm. Accessed June 1, 2003.

United States Department of the Interior, US Geological Survey. 2000. A mass-balance approach for assessing PCB movement during remediation of a PCB-contaminated deposit on the Fox River, Wisconsin. USGS Water-resources Investigations Report 00-4245. Available: http://www.dnr.state.wi.us/org/water/wm/ lowerfox/sediment/usgs_5657_report.pdf. Accessed June 1, 2003.

Watson, P. D., and R. P. Tittsler. 1961. The density of milk at low temperatures. J. Dairy Sci. 44:416.

Webb, B. H., A. H. Johnson, and J. A. Alford. 1974. Fundamentals of Dairy Chemistry. 2nd ed. The Avi Publishing Co. Westport, CT. 